\title{
Relations between liver cadmium, cumulative exposure, and renal function in cadmium alloy workers
}

\author{
H J MASON,' A G DAVISON, ${ }^{2}$ A L WRIGHT, ${ }^{1}$ C J G GUTHRIE, ${ }^{3}$ P M FAYERS, ${ }^{4}$ \\ K M VENABLES, ${ }^{2}$ N J SMITH, ${ }^{1}$ D R CHETTLE, ${ }^{3}$ D M FRANKLIN, ${ }^{3}$ M C SCOTT, ${ }^{3}$ \\ H HOLDEN, ${ }^{5}$ D GOMPERTZ, ${ }^{1}$ A J NEWMAN-TAYLOR ${ }^{2}$
}

From the Occupational Medicine and Hygiene Laboratories,' Health and Safety Executive, London NW2 6LN, Department of Occupational Medicine, ${ }^{2}$ Brompton Hospital, London SW3 6HP, Department of Physics, ${ }^{3}$ University of Birmingham, Birmingham, MRC Tuberculosis and Chest Disease Unit, ${ }^{4}$ Brompton Hospital, London SW3 6HP, and Medical Department, ${ }^{5}$ BICC, Prescot, UK

ABSTRACT Detailed biochemical investigations of renal function were made on 75 male workers exposed to cadmium and an equal number of referents matched for age, sex, and employment status. The exposed group consisted of current and retired workers who had been employed in the manufacture of copper-cadmium alloy at a single factory in the United Kingdom for periods of up to 39 years and for whom cumulative cadmium exposure indices could be calculated. In vivo measurements of liver and kidney cadmium burden were made on exposed and referent workers using a transportable neutron activation analysis facility. Significant increases in the urinary excretion of albumin, retinol binding protein, $\beta_{2}$ microglobulin, $\mathrm{N}$-acetylglucosaminidase (NAG), alkaline phosphatase, $\gamma$-glutamyl transferase and significant decreases in the renal reabsorption of calcium, urate, and phosphate were found in the exposed group compared with the referent group. Measures of glomerular filtration rate (GFR) (creatinine clearance, serum creatinine, and $\beta_{2}$ microglobulin) indicated a reduction in GFR in the exposed population. Many of these tubular and glomerular function indicators were significantly correlated with both cumulative exposure index and liver cadmium burden. Using cumulative exposure index and liver cadmium as estimates of dose, a two phase linear regression model was applied to identify an inflection point signifying a threshold level above which changes in renal function occur. Many biochemical variables fitted this model; urinary total protein, retinol binding protein, albumin, and $\beta_{2}$ microglobulin gave similar inflection points at cumulative exposure levels of about $1100 \mathrm{y} \cdot \mu \mathrm{g} / \mathrm{m}^{3}$ whereas changes in the tubular reabsorption of urate and phosphate occurred at higher cumulative exposure indices. Measures of GFR, although fitting the threshold model did not give well defined inflection points. Fewer variables fitted the two phase model using liver cadmium; those that did gave threshold levels in the range 20.3-55.1 ppm. When cadmium workers with cumulative exposure indices of less than $1100 \mathrm{y} . \mu \mathrm{g} / \mathrm{m}^{3}$ were compared with their respective referents only serum $\beta_{2}$ microglobulin and urinary NAG were significantly increased in the exposed group and these differences were not related to the degree of cadmium exposure. Simple dose response analysis of the full exposed group showed a greatly increased incidence of tubular proteinuria when the cumulative cadmium exposure index was greater than 1000 $y . \mu \mathrm{g} / \mathrm{m}^{3}$. These cumulative exposure indices are equivalent to about 20-22 years exposure at $50 \mu \mathrm{g} / \mathrm{m}^{3}$, the current occupational exposure limit used in many countries.

Adverse renal and pulmonary effects in industrial workers after long term exposure to cadmium were

Accepted 30 November 1987

(G) Crown copyright first observed by Friberg in the late 1940s.' Early studies have examined these effects using years of employment, sometimes supplemented by limited exposure data, or some general qualitative exposure assessment as indicators of cadmium dose. ${ }^{2-1}$ More 
recently, several groups have reported studies in which they have attempted to develop more quantitative dose estimates based on available longitudinal measurements of atmospheric cadmium concentrations. ${ }^{5-7}$ Such studies are few in number due to the difficulty of obtaining reliable cumulative exposure data and also have tended to include only poorly matched reference workers. The recent development of neutron activation analysis for the in vivo measurement of cadmium in the liver and kidney ${ }^{89}$ has provided an alternative approach for the estimation of a dose indicator. This in vivo technique has enabled the assessment of organ burden which may be used as an index of uptake within limits imposed by biological half lives.

The recommended occupational exposure limit for cadmium has been set to protect against the risk of renal dysfunction, usually evidenced by tubular proteinuria, after a lifetime's exposure to cadmium. Dose response data form the basis for establishing occupational exposure limits and the main response variable used to define renal dysfunction has been urinary $\beta_{2}$ microglobulin. ${ }^{10}$ This protein undergoes degradation in acidic urine $(\mathrm{pH}<5.5)$ and it has been recently suggested that retinol binding protein has advantages over $\beta_{2}$ microglobulin as an indicator of tubular proteinuria." The importance of tubular proteinuria in relation to other, possibly more clinically important, alterations in renal metabolism has not been adequately defined. There are few reports relating exposure estimates, in vivo body burden measurements, and a wide range of biochemical indicators of renal effect.

In this paper we report a study of a group of workers exposed to cadmium with detailed exposure histories of up to 39 years duration. Neutron activation analysis was used to investigate organ burden of cadmium and a comprehensive biochemical assessment of renal function was performed. Since many of the biochemical measures used to study renal function are age related, a group of unexposed reference workers who were closely matched for age as well as occupational status was included. The relation between liver cadmium as an index of body burden and a time weighted cumulative exposure index is described and models for the dose effect and dose response relations between these indices and changes in renal function are developed.

\section{Materials and methods}

\section{STUDY POPULATION}

The factory studied has produced copper-cadmium alloy, which is used for the manufacture of cables, since 1926. The alloy is produced by adding cadmium (boiling point $765^{\circ} \mathrm{C}$ ) or master copper-cadmium alloy
(50:50 alloy) to molten copper (melting point $1083^{\circ} \mathrm{C}$ ) and during the process yellow brown fumes of cad. mium oxide are evolved. The production process has remained essentially the same since the factory opened, although hygiene conditions have been much improved over the years.

Cadmium workers

All current and ex-workers who had produced coppercadmium alloy for one or more years since the factory opened were identified from company employment and transfer records. This resulted in a total of 185 subjects from the all male population of whom 76 were known to have died, three had emigrated, and three could not be traced. Of the 103 workers available for study, 101 agreed to take part in this survey. Of these, 77 were seen at the medical centre on the factory site and the remaining 24 men were seen at home and had incomplete biochemical investigations and no in vivo measurements of cadmium body burden. Only 11 workers were currently employed in the production of copper-cadmium alloy.

Referent workers

Male referent workers were selected from the current or past workforce of the same company, after matching for age (mean age difference $=0.4$ years, $\mathrm{SD}=2.5$ years). They were all hourly paid manual workers without occupational exposure to cadmium. The factory is in an area of high unemployment and many of the workers had become unemployed, almost invariably by being made redundant. Since it has been suggested that unemployment may affect health, ${ }^{12}$ individuals in the exposed group who were currently unemployed, or who were over 65 and had become unemployed before the normal retirement age of 65 , were matched, where possible, with referents of a similar employment status. Seventy out of the 77 men seen at the medical centre were matched for employment status.

Although not individually matched for smoking histories, the proportions of current smokers, exsmokers, and non-cigarette smokers and the number of pack-years were similar in both those exposed to cadmium and referent groups.

Referents for two cadmium workers aged 79 and 83 were not obtained and thus the study population described in this paper is restricted to the 75 cadmium exposed workers (mean age 55, range 22-75) who had full biochemical and in vivo neutron activation investigations together with their matched referents.

\section{STUDY PROCEDURE}

Each cadmium worker was seen at the medical centre, so far as possible at the same time of day as his matched referent worker to minimise the effects of diurnal variation on biochemical variables. Health and occupational history questionnaires were 
administered to each subject; these included questions about exposure to cadmium, questions relating to renal diseases, and smoking history. A full clinical examination was made including three measurements of blood pressure. Height and weight were recorded.

Thirty five millilitres of venous blood were collected from each subject together with a carefully timed urine sample collected over about three hours. Aliquots of plasma, serum, and urine were stored at $-70^{\circ} \mathrm{C}$ until analysis.

In vivo measurements of kidney and liver cadmium by prompt-gamma neutron activation analysis were performed using the Birmingham University mobile facility. ${ }^{1314}$ The liver and left kidney were located by ultrasound before measurement and the observed cadmium signals corrected for depth of overlying tissue.

\section{BIOCHEMICAL MEASUREMENTS}

Blood and urine cadmium concentrations were measured by graphite furnace atomic absorption spectrometry. ${ }^{1516}$ Urinary protein constituents were determined as follows: total protein using a commercial kit based on the Coomassie brilliant blue dye binding method (Environmental Chemical Specialities, Bio-Rad Ltd, USA); albumin by a modified immunoturbidimetric method $^{17}$; retinol binding protein (RBP) by an enzyme linked immunosorbent assay (ELISA), ${ }^{18}$ and $\beta_{2}$ microglobulin $\left(\beta_{2} \mathrm{mg}\right)$ with a "Phadebas" $\beta_{2}$ microtest kit (Pharmacia Diagnostics AB, Uppsala, Sweden). The following urinary enzymes were measured ${ }^{19}$ in aliquots of urine which had been desalted using Pharmacia PD-10 columns: $\mathrm{N}$-acetyl- $\beta$-D-glucosaminidase (NAG), alkaline phosphatase (ALP), and lactate dehydrogenase (LDH) were measured using a Vitatron PA800 discrete kinetic analyser and $\gamma$-glutamyltransferase (GGT) was measured by a kinetic enzyme method using a Cobas Bio centrifugal analyser (Roche Products Ltd, Welwyn Garden City, UK). Creatinine in urine was measured by the Jaffe technique using a Technicon autoanalyser. ${ }^{20}$ Other urinary constituents were determined using a Cobas Bio centrifugal analyser as follows: inorganic phosphate by a colorimetric assay based on a reaction between phosphate and a molybdate reagent (Lancer, Pierce Warriner, Chester, UK); urate by a uricase spectrophotometric method (Roche Products Ltd, Welwyn Garden City, UK) and calcium by a direct colorimetric method using methyl thymol blue (Lancer, Pierce Warriner, Chester, UK). Measurement of creatinine, $\beta_{2}$ microglobulin, phosphate, urate, and calcium in serum were made using the same methods as those used for urine except that creatinine was measured using a Cobas Bio centrifugal analyser. Fractional excretion indices for calcium and urate were calculated to express the percentage of the analyte filtered at the glomerulus which has not been reabsorbed in the tubules using the formula:

$$
\text { [plasma creatinine] } \times \text { [urine }(x)] \times 100
$$

[plasma $(x)] \times$ [urine creatinine]

where $(x)=$ calcium or urate.

To take account of the documented changes in phosphate clearance with plasma phosphate concentration and phosphate intake, ${ }^{21}$ a phosphate excretion index was calculated. ${ }^{22}$ Calculated creatinine clearance values were corrected to a standard surface area of $1.73 \mathrm{~m}^{223}$ As is common in occupational medicine, urinary analytes were expressed per millimole of excreted creatinine to reduce the effect of the state of renal diuresis on measured concentration.

\section{CUMULATIVE EXPOSURE INDEX}

A total of 933 measurements of cadmium in air had been made at the factory between 1951 and 1983 . Inhalation exposure estimates for the period 1964 to 1983 were derived using 482 of these measurements (246 area or background measurements and 236 personal exposure measurements). Simultaneous area sampling and personal exposure measurements were made on 32 days. The measurements made using personal samplers were on average $20 \%$ higher than the area measurements and this figure was used to adjust all area measurements to give estimates of personal exposures.

Before 1964 sampling and analytical methods were not well standardised and before 1951 no measurements exist. Therefore, pre-1964 exposures were estimated after discussion with the occupational health physician, occupational hygienist, management, and workforce, by consideration of the available measured levels, changes in production techniques, and changes in ventilation and production levels. The estimated level for 1963 is the same as the measured level in 1964. Table 1 tabulates exposure estimates in chronological order.

Plant personnel records and occupational history

Table 1 Inhalation exposure estimates 1926-83

\begin{tabular}{llllll}
\hline Year & $\begin{array}{l}\text { Cadmium } \\
\left(\mu \mathrm{g} / \mathrm{m}^{3}\right)\end{array}$ & $\begin{array}{l}\text { No of } \\
\text { measurements }\end{array}$ & $\begin{array}{l}\text { Year } \\
\left(\mu \mathrm{g} / \mathrm{m}^{3}\right)\end{array}$ & $\begin{array}{l}\text { No of } \\
\text { measurements }\end{array}$ \\
\hline $1926-30$ & 600 & - & 1975 & 43 & 37 \\
$1931-35$ & 480 & - & 1976 & 44 & 44 \\
$1936-42$ & 360 & - & 1977 & 48 & 31 \\
$1943-46$ & 270 & - & 1978 & 49 & 33 \\
$1947-54$ & 240 & - & 1979 & 58 & 48 \\
$1955-62$ & 210 & - & 1980 & 56 & 43 \\
$1963-72$ & 156 & 60 & 1981 & 49 & 43 \\
1973 & 85 & 27 & 1982 & 34 & 36 \\
1974 & 58 & 37 & 1983 & 36 & 43 \\
\hline
\end{tabular}


questionnaires were processed to obtain a chronological record of each subject's work history. A time weighted average inhalation exposure, taking into account changes in duration of working week, was then determined for each subject. This cumulative exposure index was calculated by summing the products of duration of time employed at a particular exposure level times that exposure over the subject's entire working history.

\section{DATA ANALYSIS}

Log transformation of data was performed before statistical analysis on those variables showing significant log-normal distributions. For the biochemical variables, in vivo kidney and body-fluid cadmium measurements, differences between values for the cadmium worker, and his matched referent were compared using a paired $t$ test. Since there are large uncertainties in the measurement of the low levels of liver cadmium found in the unexposed workers this test was not carried out on the in vivo liver measurements.

Standard linear and partial correlation analyses were performed using the matched pair differences for all variables except liver cadmium; in the case of liver cadmium the exposed workers' values alone were used. Further regression analysis using a two phase linear regression technique ${ }^{24}$ was used to estimate the inflection point or change point in any dose effect model showing a possible threshold. Cumulative exposure index or liver cadmium concentration of the exposed worker was used as the dose variable and the main criteria for accepting that a dependent variable (matched pair difference) fitted this model were that the two gradients differed significantly from each other and each phase of the regression had at least ten data points.

The upper 95th percentile for urinary retinol binding protein was calculated for the referent population and was used to define cadmium workers who were considered to have tubular proteinuria; urinary retinol binding protein was not age related in the referent population.

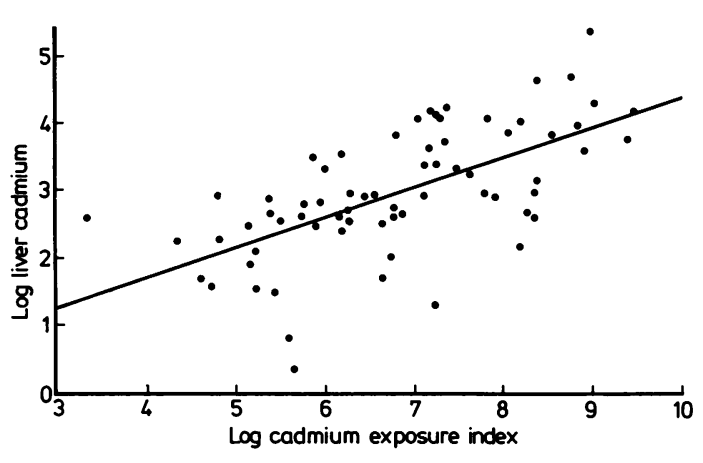

Fig 1 Relation between two possible indicators of cadmium uptake: liver cadmium and cadmium exposure index $(r=$ $0.64, p<0.0001$ ).

\section{Results}

Kidney, blood, and urine cadmium concentrations were statistically significantly higher in the group exposed to cadmium than the referents and were significantly correlated with liver cadmium and cumulative exposure index (table 2). The mean liver cadmium concentration (and SE) in the referent group was $0.6 \mathrm{ppm}(0.5)$ whereas in the log-normally distributed exposed group the geometric mean (and geometric SE) was $18.5 \mathrm{ppm}(1 \cdot 1)$. The relation between liver cadmium and cumulative exposure index is shown in fig $1(\mathrm{r}=0.64, \mathrm{p}<0.0001)$.

The urinary excretion rate of creatinine was neither significantly different between exposed and control groups $(p=0.253)$ nor correlated with the cumulative exposure index.

Urinary total protein, albumin, retinol binding protein, $\beta_{2}$ microglobulin, NAG, alkaline phosphatase, $\gamma$-glutamyl transferase, fractional excretion of calcium and urate, and serum $\beta_{2}$ microglobulin showed significant differences $(\mathrm{p}<0.01)$ between the cadmium exposed and referent groups; serum creatinine $(p=0.017)$, creatinine clearance $(p=0.034)$, and phosphate excretion index $(\mathrm{p}=0.013)$ were margin-

Table 2 Body fluid and kidney cadmium concentrations in the exposed and referent groups

\begin{tabular}{|c|c|c|c|c|c|}
\hline & \multicolumn{2}{|c|}{ Mean $(S E)$} & \multirow[b]{2}{*}{ p Value } & \multicolumn{2}{|c|}{ Correlation coefficients ( $p$ value) } \\
\hline & $\begin{array}{l}\text { Cadmium } \\
(n=75)\end{array}$ & $\begin{array}{l}\text { Referents } \\
(n=75)\end{array}$ & & $\begin{array}{l}\text { Exposure index } \\
(\log )\end{array}$ & $\begin{array}{l}\text { Liver cadmium } \\
(\log )\end{array}$ \\
\hline $\begin{array}{l}\text { Kidney cadmium }(\mathrm{mg}) \\
\text { Blood cadmium* }(\mathrm{nmol} / \mathrm{l}) \\
\text { Urine cadmium* }(\mathrm{nmol} / \mathrm{mmol} \mathrm{cr})\end{array}$ & $\begin{array}{r}18 \cdot 2(1 \cdot 6) \\
78 \cdot 0(1 \cdot 1) \\
7 \cdot 1(1 \cdot 1)\end{array}$ & $\begin{array}{r}2.9(0.4) \\
12 \cdot 8(1 \cdot 1) \\
0.8(1 \cdot 1)\end{array}$ & $\begin{array}{l}<0.0001 \\
<0.0001 \\
<0.0001\end{array}$ & $\begin{array}{l}0.43(<0.0001) \\
0.48(<0.0001) \\
0.40(<0.0004)\end{array}$ & $\begin{array}{l}0.50(<0.0001) \\
0.55(<0.0001) \\
0.55(<0.0001)\end{array}$ \\
\hline
\end{tabular}

*Geometric mean (geometric SE). 


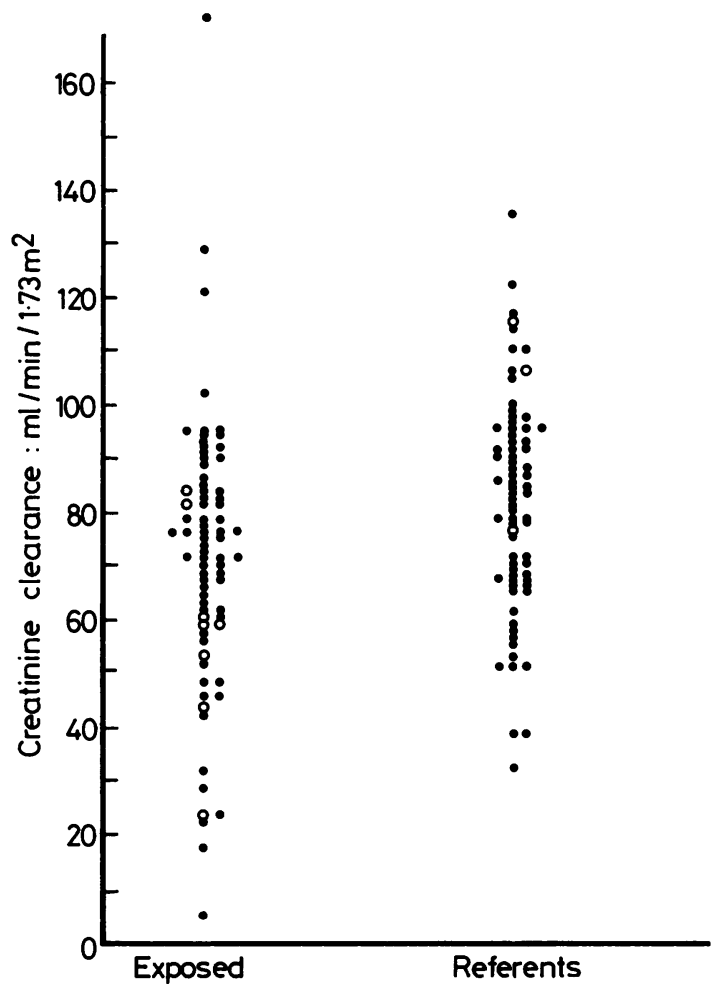

Fig 2 Creatinine clearances after correction for surface area and to age 55 years in cadmium exposed and referent groups. (Subjects taking antihypertensive treatment shown as 0 .

Table 3 Biochemical and blood pressure measurements ally less significant (table 3 ). Figure 2 shows the distribution of creatinine clearance in the two groups after adjustment to the mean age of the referents (age 55) using a regression technique. Seventeen per cent $(13 / 75)$ of the group exposed to cadmium had adjusted creatinine clearances below $50 \mathrm{ml} / \mathrm{min} / 1 \cdot 73^{2}$, compared with $4 \%(3 / 74)$ of the matched referents (chisquared test $p<0.009$ ). There was no significant difference in the systolic and diastolic blood pressure (table 3) or frequency of antihypertensive drug treatment (8/75 compared with $3 / 75$ chi-squared test $p=0 \cdot 1)$ between those exposed to cadmium and referent groups.

The relation between biochemical variables and the indicators of cadmium uptake-that is, cumulative exposure index and liver cadmium-are summarised in table 4. All of the variables which showed a significant difference between the matched populations (table 3), except creatinine clearance and urinary $\gamma$-glutamyl transferase, were significantly correlated $(\mathrm{p}<0.05)$ with the log of exposure index. Urinary $\mathrm{pH}$ and lactate dehydrogenase, which did not differ significantly between the exposed and control groups, showed a weak but significant correlation to the cadmium exposure index. The use of liver cadmium as the independent variable produced a similar pattern of significant relations for all variables except urinary $\mathrm{pH}$ and serum $\beta_{2}$ microglobulin.

Partial correlation analysis after standardising for the cadmium exposure index variable showed that blood, urine, liver, and kidney cadmium had significant negative correlations with years since exposure ceased (table 5). None of the biochemical

\begin{tabular}{|c|c|c|c|}
\hline & $\begin{array}{l}\text { Cadmium exposed } \\
\text { Mean }(S E) \\
(n=75)\end{array}$ & $\begin{array}{l}\text { Referents } \\
\text { Mean }(S E) \\
(n=75)\end{array}$ & $\begin{array}{l}\text { p Value } \\
\text { (paired t test) }\end{array}$ \\
\hline 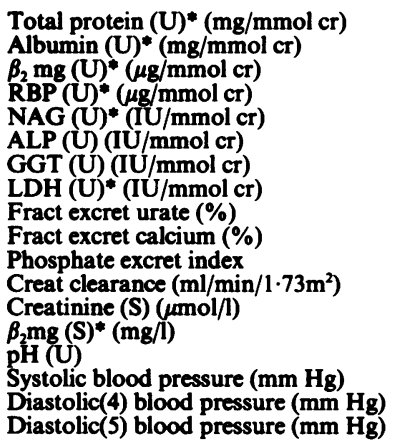 & 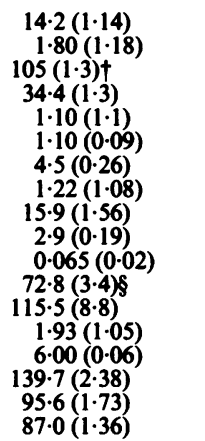 & $\begin{array}{c}7.2(1.08) \\
0.85(1.15) \\
17.5(1 \cdot 1) t \\
8.0(1 \cdot 1) \\
0.70(1.05) \\
0.81((0.04) \\
3.5(0.12) \$ \\
1.01(1.09) \\
9.6(0.35) \\
2.23(0.11) \\
0.009(0.009) \\
82.6(2.5) \S \\
93.7(1.9) \\
1.61(0.39) \\
5.90(0.08) \\
141.6(2.52) \\
93.0(1.95) \\
84.3(1.5)\end{array}$ & $\begin{array}{c}<0.0001 \\
0.0003 \\
0.0003 \\
<0.0001 \\
<0.0001 \\
0.0034 \\
0.0007 \\
0.088 \\
<0.0001 \\
0.0017 \\
0.013 \\
0.034 \\
0.017 \\
<0.0001 \\
0.297 \\
0.520 \\
0.053 \\
0.166\end{array}$ \\
\hline
\end{tabular}

$S=$ Serum, $U=$ urine.

*Geometric mean (geometric SE).

†n $=70$.

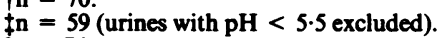

$\S \mathrm{n}=74$. 
Table 4 Correlation of biochemical variables with exposure index and liver cadmium

\begin{tabular}{|c|c|c|c|c|}
\hline & \multicolumn{2}{|c|}{ Cadmium exposure index } & \multicolumn{2}{|c|}{ Liver cadmium* } \\
\hline & $\begin{array}{l}\text { Correlation } \\
\text { coefficient } \\
(n=75)\end{array}$ & p Value & $\begin{array}{l}\text { Correlation } \\
\text { coefficient } \\
(n=69)\end{array}$ & p Value \\
\hline $\begin{array}{l}\text { Total protein }(U)^{*} \\
\text { Albumin }(U)^{*} \\
\beta_{2} \text { microglobulin } \\
(U)^{*}\end{array}$ & $\begin{array}{l}0.57 \\
0.39 \\
0.66+\end{array}$ & $\begin{array}{r}<0.0001 \\
0.0016 \\
<0.0001\end{array}$ & $\begin{array}{l}0.56 \\
0.42 \\
0.66 \ddagger\end{array}$ & $\begin{array}{r}<0.0001 \\
0.0004 \\
<0.0001\end{array}$ \\
\hline $\begin{array}{l}\text { RBP(U)* } \\
\text { NAG (U)* } \\
\text { ALP(U) } \\
\text { GGT (U) } \\
\text { LDH (U)* } \\
\text { Fract excret urate } \\
\text { Fract excret } \\
\text { calcium }\end{array}$ & $\begin{array}{l}0.65 \\
0.32 \\
0.35 \\
0.208 \\
0.24 \\
0.44 \\
0.37\end{array}$ & $\begin{array}{c}<0.0001 \\
0.0048 \\
0.0023 \\
0.094 \\
0.041 \\
<0.0001 \\
0.0009\end{array}$ & $\begin{array}{l}0 \cdot 60 \\
0 \cdot 44 \\
0 \cdot 29 \\
0 \cdot 18 \| \\
0 \cdot 26 \\
0 \cdot 53 \\
0 \cdot 29\end{array}$ & $\begin{array}{c}<0.0001 \\
0.0002 \\
0.014 \\
0.134 \\
0.032 \\
<0.0001 \\
0.016\end{array}$ \\
\hline $\begin{array}{l}\text { Phosphate } \\
\text { excretion index }\end{array}$ & $0 \cdot 39$ & 0.0006 & 0.33 & 0.006 \\
\hline $\begin{array}{l}\text { Creatinine } \\
\text { clearance }\end{array}$ & $-0.22 \S$ & 0.058 & $-0.08 \|$ & 0.545 \\
\hline $\begin{array}{l}\text { Creatinine (S) } \\
\beta_{2} \text { microglobulin } \\
(\mathbf{S})^{*}\end{array}$ & $\begin{array}{l}0 \cdot 37 \\
0 \cdot 39\end{array}$ & $\begin{array}{l}0.001 \\
0.0005\end{array}$ & $\begin{array}{l}0.31 \\
0.17\end{array}$ & $\begin{array}{l}0.009 \\
0.159\end{array}$ \\
\hline pH (U) & $0 \cdot 246$ & 0.033 & $0 \cdot 17$ & $0 \cdot 165$ \\
\hline
\end{tabular}

$S=$ Serum, $U=$ urine.

* Log transformed variables.

tn $=54$ (urines with $\mathrm{pH}<5.5$ excluded).

tn $=48$ (urines with $\mathrm{pH}<5.5$ excluded).

§n $=74$.

$\| \mathrm{n}=68$.

variables shown in table 3 , except urinary $\mathrm{pH}$, showed any significant correlation with this time variable.

Table 6 shows the inflection points and 95\% confidence intervals using the two phase linear regression model for those variables fitting this model. Figure 3 shows the model using urinary retinol binding protein plotted against cumulative cadmium exposure index. All variables, except creatinine clearance and kidney and urine cadmium, showed a similar pattern to fig 3 using the cadmium exposure index as independent variable - that is, a significant positive second phase gradient compared with the first gradient (creatinine clearance showed a significant negative second phase gradient compared with the first). When urinary and kidney cadmium were plotted against the exposure index, however, both showed a positive first phase gradient with the gradient after the inflection

Table 5 Partial correlation coefficients with number of years off exposure (allowing for the effect of cadmium exposure index)

\begin{tabular}{lcc}
\hline Variable & $R$ (partial) & $p$ Value \\
\hline Liver cadmium* & -0.236 & 0.043 \\
Kidney cadmium $_{\text {Blood cadmium* }}^{*}$ & -0.503 & $<0.0001$ \\
Urine cadmium* & -0.291 & 0.012 \\
Urine pH & -0.476 & $<0.0001$ \\
& 0.257 & 0.027 \\
\hline
\end{tabular}

${ }^{*}$ Log transformed variables.
Table 6 Two phase linear regression model

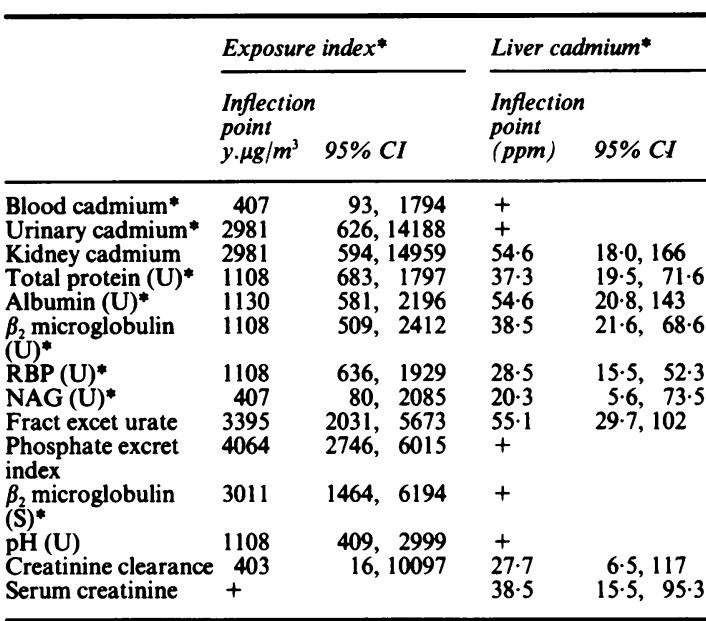

* Log transformed variables; figures in table have been anti-logged.

+Does not fit the two phase linear regression model.

point being not significantly different from zero. Fewer variables fitted the two phase linear regression model using liver cadmium as the independent variable but the overall pattern was similar.

Biochemical variables for those cadmium workers with cumulative exposure indices less than 1100 $\mathrm{y} . \mu \mathrm{g} / \mathrm{m}^{3}$ were compared with their respective referents $(\mathrm{n}=43)$. The cut off of $1100 \mathrm{y} \cdot \mu \mathrm{g} / \mathrm{m}^{3}$ was chosen since this is the common inflection point for urinary proteins using the two phase linear regression model (table 6). Only the in vivo liver and kidney cadmium, blood and urine cadmium concentrations, urinary NAG, and serum $\beta_{2}$ microglobulin were now significantly different between groups $(\mathrm{p}<0.05)$ (cf table 3). Urinary NAG and serum $\beta_{2}$ microglobulin, however, were not significantly correlated with the exposure index in this subgroup ( $p>0.05)$.

Figure 4 shows the frequency of tubular proteinuria in the full cadmium exposed group $(n=75)$ after dividing the workers into six exposure ranges.

\section{Discussion}

In this survey we attempted to study all workers still living who had ever been employed for more than one year in the manufacture of copper-cadmium alloy at this factory. Of the 101 workers who were traced, the 75 subjects with their respective referents who had full biochemical investigations at the medical centre form the basis of this paper. The mean age for this study population (55, range 22-75), therefore, tends to be somewhat older than in many occupational health studies. The well documented functional and 


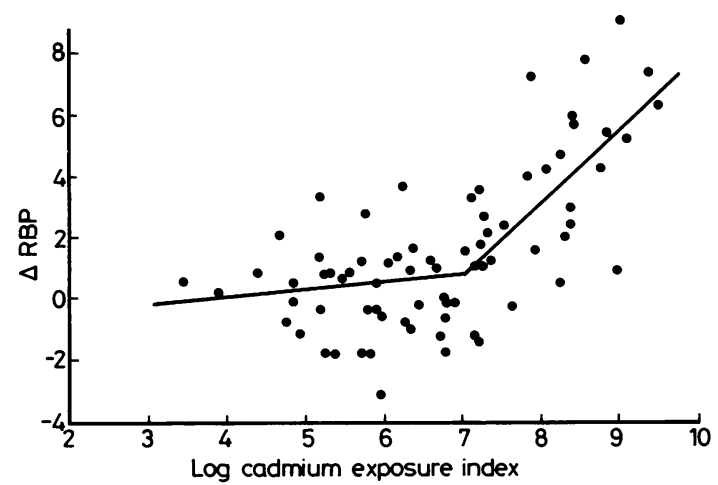

Fig 3 Two phase linear regression plot of matched pair differences of urinary retinol binding protein $(\triangle R B P)$ versus cumulative exposure index.

anatomical changes in the kidney with age ${ }^{25} 26$ and the possible effect of employment status on health ${ }^{12}$ are such that in an occupational health survey of a nephrotoxin such as cadmium careful selection of a well matched control group is necessary. By contrast with many studies of cadmium toxicity, this study included referent workers who had been carefully matched for age and, where possible, employment history status.

The in vivo measurements of liver and kidney cadmium and the blood and urine cadmium concentrations show that the uptake of cadmium within a proportion of the exposed group has been substantial (table 2) and is comparable with other published occupational surveys of cadmium workers which have included in vivo neutron activation analysis measurements. ${ }^{27}$ Many of the exposed population had ceased working with cadmium many years before our study (median $=8$ years; range $=0-44$ years). Therefore, cadmium body burden and cadmium concentrations in body fluids would have been affected by the concentration decay (half lives) of cadmium in the body. Biological half lives of cadmium, although ill defined, ${ }^{28}$ have been variously reported as $7 \cdot 4$ to 16 years for blood, ${ }^{29}$ and using in vivo measurements as between 10 and 30 years for kidney and 4.7 to 9.7 years for liver.$^{30}$ Thus our liver cadmium measurements may underestimate the extent of cadmium exposure and uptake in retired workers. The partial correlation coefficients shown in table 5, suggesting that there is a significant negative correlation between the cadmium measurements and length of time since occupational exposure to cadmium ceased, are consistent with this hypothesis.

The use of creatinine correction for urinary constituents was supported by the lack of significant differences in the rate of creatinine excretion between exposed and control groups and the absence of any relation with the cadmium exposure index. The significant differences in biochemical measures between groups (table 3 ) indicate a qualitative effect on renal function whereas the correlation data shown in table 4 imply that the degree of cadmium exposure exerts a quantative adverse effect. There is a lack of relation between "years off exposure" with all biochemical measures except urinary $\mathrm{pH}$, when standardising for cadmium exposure index in partial correlation analysis. This may suggest that any progressive increase in dysfunction occurring after the end of exposure is not significant compared with that which can be accounted for directly by cumulative cadmium exposure.

In the present study a range of biochemical measures was used to investigate the tubular component of kidney dysfunction. Defects in tubular reabsorption of proteins were shown by a large increase in excretion of those measured proteins filtered freely by the glomeruli, $\beta_{2}$ microglobulin, and retinol binding protein. There is a smaller increase in

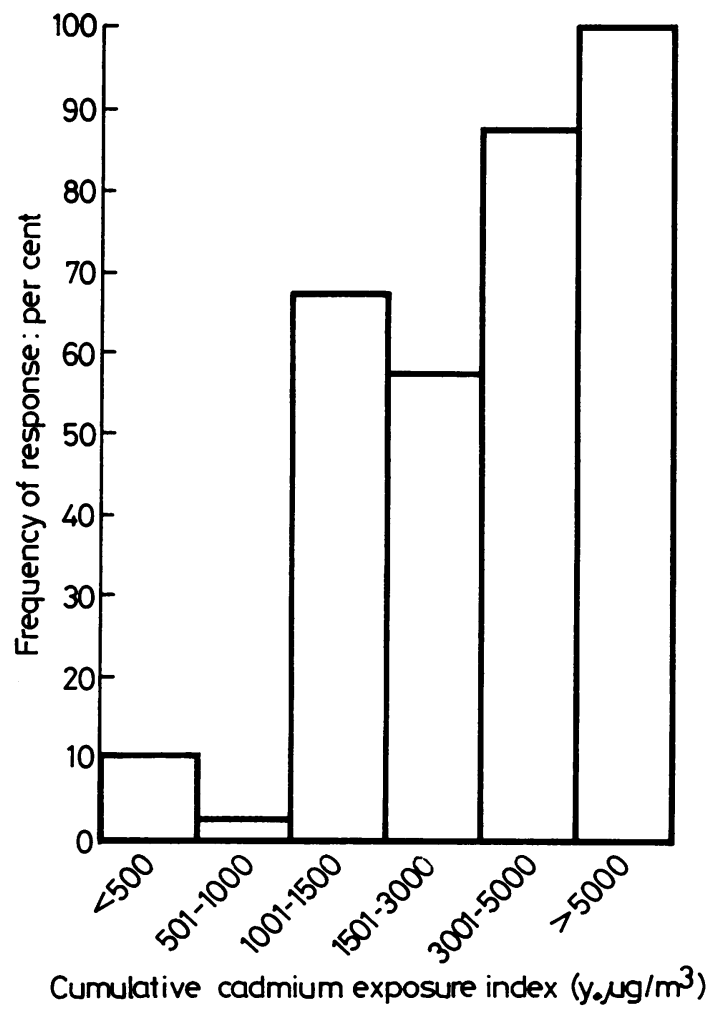

Fig 4 Frequency of tubular proteinuria in exposed workers, grouped according to cumulative exposure index. Cadmium workers were considered to have tubular proteinuria if their urinary $\mathbf{R B P}$ exceeded 95 th percentile calculated for referent population. 
the excretion of the higher molecular weight protein, albumin, which although largely hindered at the glomerulus also undergoes substantial reabsorption from the filtrate. Modest increases in urinary albumin concentration may thus be explained as a result of damage to the proximal tubules without the need to postulate alteration in glomerular permeability. Urinary total protein concentration was also significantly higher in the exposed group, although there is evidence that the analytical technique we used may be less sensitive to the detection of tubular rather than glomerular proteinuria. ${ }^{31}$ Calcium, urate, and phosphate each have an active transport mechanism in the proximal tubule of the nephron as a component of their renal handling and thus the observed increases in the fractional excretion of these analytes are compatible with a generalised proximal tubular dysfunction. Similar increases have been reported in a study of alkaline battery workers. ${ }^{32}$ Increases in excretion of the urinary enzymes of lysosomal origin (NAG) and of brush border origin (GGT and ALP) have been reported in both animal and human studies. ${ }^{32-35}$ All three enzymes are found in high concentrations in proximal tubular cells and raised urinary levels probably signify disturbance of proximal cell metabolism or cell turnover. ${ }^{36}$

Three indicators of glomerular filtration rate (GFR) were measured. Serum creatinine and serum $\beta_{2}$ microglobulin are relatively insensitive to small changes in GFR $^{37}$ and creatinine clearance measurements suffer a degree of imprecision even in well collected 24 hour samples. ${ }^{38}$ The validity of a creatinine clearance calculated over three hours and the use of age correction is supported by the close agreement found between our data for the reference group (mean clearance at age $55=81 \mathrm{ml} / \mathrm{min} / 1 \cdot 73^{2}$, $\mathrm{SD}=20$ ) and published figures for healthy men (mean clearance, age span 50 to $59=81 \mathrm{ml} / \mathrm{min} /$ $\left.1 \cdot 73^{2}, \mathrm{SD}=21\right){ }^{39}$ Despite the above limitations all three measures indicated a reduction in GFR in the group exposed to cadmium compared with the referent population.

Whereas there were no significant differences in systolic and diastolic blood pressure or frequency of antihypertensive drug treatment between those exposed to cadmium and referent groups as a whole, there appeared to be a cluster of treated hypertensives among the cadmium workers with lower creatinine clearances (fig 2). Certain antihypertensive drugs are known to reduce GFR. ${ }^{40}$ Therefore, there are at least three possible explanations for the alteration in creatinine clearance. Possibly cadmium affects the glomerulus either directly or indirectly through the tubuloglomerular feedback mechanism as a result of cadmium interference with the proximal reabsorption of sodium and chloride. ${ }^{4142}$ Alternatively, there may be increased sensitivity of the cadmium compromised kidney to antihypertensive treatment. On the basis of the data available we cannot conclude whether any one or combination of these mechanisms could be responsible.

It has been suggested from animal studies that raised intracellular cadmium concentrations in the kidney may be accommodated by the induction of the cadmium binding protein, Cd-metallothionein, ${ }^{43}$ until the capacity of the renal cell to increase Cd-metallothionein synthesis is exceeded. The resulting increased free intracellular cadmium then interferes with normal cellular metabolism. This model suggests a threshold mechanism where no significant change in renal function is observed until a critical kidney cadmium concentration is reached and thereafter the dysfunction is possibly related to the concentration of nonmetallothionein bound cadmium. For this reason we examined a two phase regression model to study the relation between renal function variables and exposure estimates. It should be noted that in this model both cumulative exposure index and liver cadmium concentration are assumed to be directly related to the cadmium burden causing dysfunction in the target organ - that is, the kidney.

Data in table 6 suggest that, using the cadmium exposure index as a dose estimate, this two phase model is satisfied for many of the renal biochemical variables relating both to tubular reabsorptive processes and GFR. The mean inflection points for urinary total protein, albumin, $\beta_{2}$ microglobulin, and retinol binding protein are similar at about $1100 \mathrm{y} . \mu \mathrm{g} / \mathrm{m}^{3}$, suggesting that all four measures are in fact describing the effect of cadmium on the same specific renal process-that is, the tubular reabsorption of proteins. ${ }^{445}$ The fractional excretion indices of urate and phosphate have significantly higher mean inflection points than the urinary proteins. This suggests that changes in these reabsorptive processes occur either at higher target organ dose or possibly that the non-proximal tubular element of their more complex renal handling is altered, perhaps in the case of phosphate being influenced hormonally. Two measures of GFR, serum $\beta_{2}$ microglobulin and creatinine clearance, satisfied the necessary criteria for the two phase regression model using cumulative exposure index but there was a large uncertainty in the inflection points. The inflection point obtained for urinary NAG against cadmium exposure index may reflect the early disturbances in the lysosomal system that have been reported in studies of animal models of the cellular effects of cadmium nephrotoxicity. ${ }^{46}$ The two phase model for kidney cadmium against cadmium exposure index, which shows a secondary nonsignificant gradient after the positive initial phase, possibly reflects the accelerated rate of cadmium loss 
from this organ after the development of renal dysfunction.

Fewer biochemical variables fitted the two phase model using liver cadmium as indicator of body burden. Those that did (total protein, albumin, $\beta_{2}$ microglobulin, retinol binding protein, NAG, fractional excretion of urate, serum creatinine, and creatinine clearance) gave mean inflection points in the range $20 \cdot 3-55 \cdot 1 \mathrm{ppm}$ liver cadmium. This range of liver cadmium inflection points encompasses values found in two surveys reported by Chettle et al using total protein and $\beta_{2}$ microglobulin as response variables, ${ }^{47}$ and is similar to the value of $40 \mathrm{ppm}$ quoted by Ellis $e t$ al who used $\beta_{2}$ microglobulin as an indicator of change in renal status. ${ }^{30}$

The wide confidence intervals associated with the various inflection points when using either cadmium exposure index or liver cadmium may be a consequence of several factors; the interindividual and intraindividual variation in the biochemical parameters measured, the inherent errors in estimating a historical exposure index, the effect of biological half life of cadmium in the liver, and also that, within a population, there will be a range of thresholds corresponding to an individual's ability to induce increased amounts of intracellular metallothionein.

Using the cumulative exposure index, changes in the tubular reabsorption of proteins appear at similar inflection points of about $1100 \mathrm{y} . \mu \mathrm{g} / \mathrm{m}^{3}$ with lower $95 \%$ confidence limits of $500-700 \mathrm{y} \cdot \mu \mathrm{g} / \mathrm{m}^{3}$. These values are similar to those of Ellis et al who used a logistic regression model, with $\beta_{2}$ microglobulin, as the response variable. ${ }^{30}$ Their model predicted $59 \%$ renal dysfunction at cumulative exposures over $1100 \mathrm{y} . \mu \mathrm{g} /$ $\mathrm{m}^{3}$ and suggested that dysfunction may occur at between $400-500$ y. $\mu \mathrm{g} / \mathrm{m}^{3}$. Simple dose response analysis of our data (fig 4) using urinary retinol binding protein as the response variable shows that at cumulative exposures between 1000 and $1500 \mathrm{y} . \mu \mathrm{g} / \mathrm{m}^{3}$ there is a qualitative change in renal function. Below this exposure range the frequency of retinol binding proteinuria is no greater than that found in the referent population; within and above this exposure range the prevalence of this proteinuria is greater than $55 \%$.

When those cadmium workers with cumulative exposure indices above $1100 \mathrm{y} . \mu \mathrm{g} / \mathrm{m}^{3}$ and their respective controls were excluded from the population only two biochemical variables, serum $\beta_{2}$ microglobulin and urinary NAG, showed significant differences between exposed and referent groups. The degree of both differences was unrelated to the cadmium exposure index. Urinary NAG may be marginally increased in many renal pathological conditions and in the renal handling of several drugs at therapeutic levels. The statistically significant but small increase in serum $\beta_{2}$ microglobulin seen in this subgroup analysis may suggest some reduction in GFR, although apparently not directly related to the amount of cadmium exposure. The lack of substantiation by the other measures of GFR, however, could be interpreted as indicating a small alteration in the production rate of $\beta_{2}$ microglobulin rather than its renal handling.

In summary, this study confirms other surveys of cadmium workers which have found evidence of generalised dysfunction of reabsorptive processes located in the proximal tubules and damage to these cells. We have shown that these effects are related to the degree of cadmium exposure as measured by cumulative exposure index and liver cadmium concentration. The progressive element of all dysfunctions (except the excretion of hydrogen ions) in the absence of continuing exposure, does not appear to be significant compared with that which can be accounted for by cumulative cadmium exposure. Many of the biochemical variables related to tubular and glomerular filtration fit the dose effect model developed from the known intracellular metabolism of cadmium. The statistically, and possibly clinically, significant changes in GFR also appear to be related by some mechanism to exposure to cadmium, although the physiological balance mechanisms between tubular and glomerular functions do not allow definition of the specific site of the cadmium effect. The effect of antihypertensive treatment on GFR may confound, to an extent, the observed reduction between exposed and control groups.

Several investigators have attempted to develop quantitative estimates of cumulative cadmium exposure and to relate these to changes in renal function. Ellis et al reported evidence of renal abnormalities when the exposure index exceeded 400-500 $\mathrm{y} . \mu \mathrm{g} / \mathrm{m}^{3} .{ }^{30}$ Smith et al reported significant renal effects with average cumulative inhalation exposures of 1575 $\mathrm{y} . \mu \mathrm{g} / \mathrm{m}^{3}{ }^{5}$. Falck et al suggested that those cadmium workers with renal dysfunction had a mean exposure of $1137 \mathrm{y} . \mu \mathrm{g} / \mathrm{m}^{36}$ and Elinder et al found only a few cases of slight $\beta_{2}$ microglobulinuria in workers with cumulative exposures of less than $1000 \mathrm{y} . \mu \mathrm{g} / \mathrm{m}^{3} .^{7}$ Dose effect, dose response, and subgroup analysis of our data suggest that a maximum level of $1100 \mathrm{y} \cdot \mu \mathrm{g} / \mathrm{m}^{3}$ may prevent the development of changes in renal function. This cumulative exposure index is equivalent to about 22 years exposure at $50 \mu \mathrm{g} / \mathrm{m}^{3}$, the current occupational exposure limit used in many countries.

We thank Mr D O'Malley and Sister Tweed (BICC) for their invaluable help during the course of the study.

\section{References}

1 Friberg $L$. Health hazards in the manufacture of alkaline accumulators with special reference to chronic cadmium 
poisoning. Acta Med Scand 1950;138 suppl 240:1-124

2 Lauwerys RR, Buchet JP, Roels HA, Brouwers J, Stanescu D. Epidemiological survey of workers exposed to cadmium: effect on lung, kidney and several biological indices. Arch Environ Health 1974;28:145-8.

3 Bonnell JA. Emphysema and proteinuria in men casting copper cadmium alloys. Br J Ind Med 1955;12:181-97.

4 Holden $H$. Health status of European cadmium workers. In: Occupational exposure to cadmium. London: Cadmium Association, 1980:330-7.

5 Smith TJ, Anderson RJ, Reading JC. Chronic cadmium exposures associated with kidney function effects. Am J Ind Med 1980;1:319-37.

6 Falck FY, Fine LJ, Smith RG, et al. Occupational cadmium exposure and renal status. Am J Ind Med 1983;4:541-9.

7 Elinder C-G, Edling C, Lindberg E, Kagedal B, Vesterberg $O$. $\beta_{2}$ Microglobulinuria among workers previously exposed to cadmium: follow up and dose-response analysis. $\mathrm{Am} \mathrm{J} \mathrm{Ind} \mathrm{Med}$ 1985;8:553-64.

8 McLellan JA, Thomas BJ, Fremlin JH, Harvey TC. Cadmiumits in vivo detection in man. Phys Med Biol 1975;20:88-95.

9 Thomas BJ, Harvey TC, Chettle DR, McLellan JS, Fremlin JH. A transportable system for the measurement of liver cadmium in vivo. Phys Med Biol 1979;24:434-7.

10 Stewart $M$, Hughes EG. Urinary $\beta_{2}$ microglobulin in the biological monitoring of cadmium workers. Br J Ind Med 1981;38:170-4.

11 Bernard AM, Lauwerys RR. Retinol binding protein in urine, a more practical index than urinary $\beta_{2}$ microglobulin for the screening of renal tubular function. Clin Chem 1981;27:1781-2.

12 Farrow SC. Monitoring the health effects of unemployment. $J R$ Coll Physicians Lond 1983;17:99-105.

13 Scott MC, Chettle DR, Coward SA, Faddy M, Fletcher JG. Developments in in vivo analysis of cadmium in the liver and kidney. Transactions of the American Nuclear Society 1983;44:33-4.

14 Scott MC, Chettle DR. In vivo elemental analysis in occupational medicine. Scand J Work Environ Health 1986;12:81-96.

15 Delves HT, Woodward J. Determination of low levels of cadmium in the blood by electrothermal atomisation and atomic absorption spectrophotometry. Atomic Spectroscopy 1981;2:65-7.

16 McAughey JJ, Smith NJ. The direct determination of cadmium in urine by electrothermal atomic absorption spectrometry with the L'vov platform. Anal Chim Acta 1984;156:129-37.

17 Spencer K, Price CP. Kinetic immunoturbidimetry: the estimation of albumin. Clin Chem Acta 1979;95:263-76.

18 Topping MD, Forster HW, Dolman C, Luczynska CM, Bernard AM. Measurement of urinary retinol binding protein by enzyme-linked immunosorbent assay, and its application to detection of tubular proteinuria. Clin Chem 1986;32:1863-6.

19 Maruhn D, Fuchs I, Mues G, Bock K. Normal limits of urinary excretion of eleven enzymes. Clin Chem 1976;22:1567-74.

$20 \mathrm{Jaffe}$ M. Measurement of creatinine using picric acid. Zeitshrift für Physiologische Chemie 1886;10:391-400.

21 Stanbury SW. Some aspects of disordered renal tubular function. Adv Intern Med 1958;9:231-82.

22 Fraser R, MacIntyre I. Disorders of bone and calcium metabolism. In: Thompson RH, Wootton ID, eds. Biochemical disorder in human disease. London; Churchill 1970:769-70.

23 Dubois D, Dubois EF. Clinical calorimetry. Tenth paper. A formula to estimate the approximate surface area if height and weight be known. Arch Intern Med 1916;17:863-71.

24 Coward SA. Cadmium in human liver and kidney. Birmingham: University of Birmingham, 1981. (MSc Thesis.).

25 Epstein M. Effects of aging on the kidney. Fed Proc 1979;38: 168-71.

26 Friedman SA, Raizner AE, Rosen H, Solomon N, Sy W. Functional defects in the aging kidney. Ann Intern Med 1972;76:41-5.

27 Roels HA, Lauwerys RR, Buchet JP, et al. In vivo measurement of liver and kidney cadmium in workers exposed to this metal: its significance with respect to cadmium in blood and urine. Environ Res 1981;26:26:217-45.

28 Kjellstrom T, Nordberg GF. Kinetic model of cadmium metabolism. In: Friberg L, Elinder C-G, Kjellstrom TK, Nordberg GF, eds. Cadmium and health; a toxicological and epidemiological appraisal. Vol 1. Boca Raton: CRC Press Inc, 1985:183.

29 Jarup L, Rogenfelt A, Elinder C-G, Nogawa K, Kjellstrom T. Biological half-time of cadmium in blood of workers after cessation of exposure. Scand J Work Environ Health 1983;9:327-31.

30 Ellis KJ, Cohn SH, Smith TJ. Cadmium inhalation exposure estimates: their significance with respect to kidney and liver cadmium burden. J Toxicol Environ Health 1985;15:173-87.

31 Goren MP, Li JTL. The Coomassie brilliant blue method underestimates drug-induced tubular proteinuria. Clin Chem 1986;32:386-8.

32 Adams RG, Harrison JF, Scott P. The development of cadmium induced proteinuria, impaired renal function and osteomalacia in alkaline battery workers. $Q J$ Med 1969;38:425-43.

33 Nomiyama K, Nomiyama $H$. Tissue metallothioneins in rabbits chronically exposed to cadmium, with special reference to the critical concentration in the renal cortex. In: Foulkes EC, ed. Biological roles of metallothionein. New York: Elsevier, 1982:47-67.

34 Gompertz D, Chettle DR, Fletcher JG, et al. Renal dysfunction in cadmium smelters: relation to in vivo liver and kidney cadmium concentration. Lancet 1983; i:1185-7.

35 Honda R, Yamada Y, Kido T, et al. Urinary N-acetyl glucosaminidase as biological indicator of renal damage due to environmental cadmium exposure. Journal of the Kanazawa Medical University 1983;8:248-56. (Japanese with English summary.)

36 Bernard AM. Evaluation of renal dysfunction induced by cadmium in man by determination of enzymes and specific proteins in urine. Arch Toxicol 1980;4 suppl:223-32.

37 Wibell L, Evrin PE, Berggard I. Serum $\beta_{2}$ microglobulin in renal diseases. Nephron 1973;10:320-31.

38 Chantler C, Barratt TM. Estimations of glomerular filtration rate from the plasma clearance of ${ }^{51}$ chromium edetic acid. Arch Dis Child 1972;47:613-7.

39 Kempmann J, Siersback-Nielsen K, Kristersen M, Hansen JM. Rapid evaluation of creatinine clearance. Acta Med Scand 1974;196:517-20.

40 Ibsen $\mathbf{H}$, Sederberg-Olsen $P$. Changes in glomerular filtration rate during long-term treatment with propanalol in patients. Clin Sci 1973;44:129-34.

41 De Wardener HE. The control of sodium excretion. Am J Physiol 1978;235:163-73.

42 Schnermann J, Levine DZ. Tubular control of glomerular filtration rate in single nephrons. Can J Physiol Pharmacol 1975;53:325-9.

$43 \mathrm{Kjellstrom} \mathrm{T.} \mathrm{Renal} \mathrm{effects-mechanism} \mathrm{for} \mathrm{the} \mathrm{development} \mathrm{of}$ renal damage. In: Friberg L, Elinder C-G, Kjellstrom TK, Nordberg GF, eds. Cadmium and health; a toxicological and epidemiological appraisal. Vol 2. Boca Raton: CRC Press Inc, 1985:71.

44 Berggard I. Plasma proteins in normal urine. In: Manuel Y, Revillard JP, Betnel HC, eds. Protein in normal and pathological urine. Basel: Karger, 1970:7-19.

45 Maack T, Johnson V, Kau ST, Figuerredo J, Sigulem D. Renal filtration, transport, and metabolism of low-molecular weight proteins: a review. Kidney Int 1979;16:251-70.

46 Squibb KS, Pritchard JB, Fowler BA. Cadmium metallothionein nephropathy: relationship between ultrastructural biochemical alterations and ultracellular cadmium binding. $J$ Pharmacol Exp Ther 1984;229:311-21.

47 Chettle DR, Coward S, Faddy MJ, et al. Cadmium renal effect levels estimated from analysis of liver and kidney concentrations. In: Wilson D, Volpe RA, eds. Proceedings of the 4th International Cadmium Conference, Munich, 1983. London: Cadmium Association, 1984:172-4. 